\title{
Ecological and Social Evaluation of Coastal Tourism Destination Development: A Case Study of Balekambang, East Java
}

\author{
Luchman Hakim, Catur Retnaningdyah, Mukhzayadah \\ Biology Department, Faculty of Mathematic and Science, Brawijaya University, Malang, Indonesia
}

\begin{abstract}
Tourism is an important sector in developing countries to support economic growth, and coastal areas are famous destinations in tourism. The plan and design for Balekambang coastal area as a tourism destination in East Java, Indonesia has been formulated and published. However, it seems lack ecological and social perspectives. This study examines coral reefs structure as one of the ecological parameter and tourist perspectives as social parameter for destination development evaluation. Twenty belt-transects were established along Balekambang coastline, and then divided into three sections, the east, the centre and the west sections. Every belt-transect was $200 \mathrm{~m}$ in length and consists of 15 plots $1 \times 2 \mathrm{~m}$. The tourist perspectives to Balekambang were determined using questionnaire among 234 respondents. Based on the Morisita similarity index, the coral reef of east section consists of 2 zones, the centre consists of 5 zones and west section consists of 4 zones. The Shannon diversity index $\left(\mathrm{H}^{\prime}\right)$ among zones at every location was ranged. The diversity index of the east section ranged from 2.07 to 2.72 , the central section ranged from 1.32 to 4.20 , and the west section ranged from 3.13 to 4.20. Zones that were close to the coastline had lowest diversity indices than zones that located far from the coastline. Mostly, tourists stated that Balekambang was interesting, but the attractions of tourism should be added. Respondent knew there were forest surrounding Balekambang, and it has the possibility to develop as tourism destination. These findings argue that the forest conversion to cottage area that planned by the local government in the west section should be reviewed. It seems forest in the west section should be developed as a forest park to meet tourist needs and redistribute tourist concentration in the coastline.
\end{abstract}

Keywords: Ecological and social evaluation, coastal, tourism, sustainable development, East Java.

\section{INTRODUCTION}

The term of coastal describes a location as being on or near a coast. Tropical coasts, ecologically, has diverse ecosystem adjacent to the coastline such as coral reefs, seagrass meadows, open sandy, rocky shores, mangrove, and lowland tropical forest. Among the coastal ecosystems, the attentions to coral reefs are increase since the ecosystem threatened seriously. Coral reefs are known rich and diverse in species that interact which each other to form extremely complex communities in the earth. Coral reefs are formed by compacted and cemented skeletons of marine invertebrates belonging to the phylum Coelenterata and class Anthozoa. Such animals are sessile species living primarily in colonies of individual polyps [1]; [2]; [3].

The roles of coral reefs are numerous, from economic to ecological benefits. Coral reefs play an essential economic role for many coastal

Corresponding Author:

Email : luchman@ub.ac.id

Address : Biology Department, Faculty of Mathematic and Science, Brawijaya University, Malang, Indonesia human communities, as they provide a habitat for fisheries, a source of marketable materials and goods, and an attraction for tourists. Ecologically, coral reef has high gross primary productivity producing 3,000-7,000 g carbon $/ \mathrm{m}^{2} /$ year. Coral reefs are home of numerous marine creatures such as, echinoderms, giant clams, turtle, sea snake and reef fishes. This ecosystem has an important role to protect shoreline from erosion, abrasion and coastal damage. Coral reefs can also transform, detoxify, and sequester wastes released by human [4]; [5]; [6].

The diversity of living creature of coastal area is huge and presents the best area for leisure. The coastal has long been a magnet for tourist, and tourism in coastal area grows rapidly throughout the world. The images such as clean water, healthy coastal habitat, safe, secure, and enjoyable environment are clearly the main specific factors for coastal tourism, and it is fundamental factors to the successful of coastal tourism [4];[7]. The coastal become popular destination due to the recreational activities such as swimming, fishing, surfing, boating and sun bathing. However, increasing number of tourism among coastal destination has affect coastal ecosystems destination, especially coral reefs. 
Many scholars argues that sustainable uses should be promoted and implemented to meet coral reefs sustainability, particularly coastal as tourism destination [8]; [4]; [9]; [10].

The sustainable tourism has introduced throughout the world as a new paradigm of tourism development. The term of sustainable tourism is derived from sustainable development that introduced at 1987 in the report entitled Our Common Future by World Commission on Environment and Development. In general, sustainable tourism seeking a more productive and harmonious relationship between visitor, local community and ecosystem destination without depleting natural resources [11]. Hence, the ecological and social evaluation has uses intensively to reach sustainable development in wide development issues in agriculture, plantation, urban planning and tourism [12]; [13]; [14].

Many example of tourism development practices, evaluation and monitoring has come from western country, but less study has been conducted in developing country like in Indonesia, where the coastal area has been intensively used as tourism destination. In this study, we examining the coral reef ecosystem structure of Balekambang at East Java, assessing tourist attitudes and proposing ecological and social information for destination development to meet coastal sustainability.

\section{METHODS}

Study site

Balekambang is the famous coastal tourism destination in East Java Province, Indonesia. It is located at southern part of Malang regency as the main tourism zone of East Java. Beauty coastal ecosystem and white sandy beach were promoted as tourism object. Ecologically, the sandy beach vegetation divided into two formation, Baringtonia formation and Ipomoea pes-caprae formation. Baringtonia formation dominated by Baringtonia asiatica, Calophyllum inophyllum, Hibiscus sp., Pandanus tectorius and several herbs species. The species of aquatic ecosystem (known as intertidal marine life zone) are diverse from invertebrate to vertebrate animals, as well as from algae to spermatophytes plants. Within the intertidal zone, coral reefs spread from west to the east and distribute between high and low tide zone, and it is become spectacular seascape of Balekambang. During low tide, tourist can walk along intertidal zone to observe coral reef diversity, collect fish and marine creatures, and other activities. Two small islands exist in the front of the beach, namely Ismoyo Island and Hanuman Island. Both of these become interested tourism object, particularly in Ismoyo Island where Hindus temple stands in the center of island.

Balekambang receive a lot of tourist and contribute significant economic benefits for local government. Because of this situation, the planning for Balekambang development was formulated and released in 1994. The concerned authority believes that the benefits will multiple in the future [15];[16]. The documents state that tourist arrival in 2000 will reach 215,778 visitors, and in 2004 it will reach 2,733,608 visitors [16]. However, after 1997, the number of tourist arrival was decreased and the projection did not attain. The economic crisis happened in the end of 1997 and decreased in environmental quality were the factors to lead tourism growth tend to decrease [17].

According to the site plan documents, coastal zone of Balekambang will be divided into several zoning such as entrance zone, infrastructures development zones, restaurants and souvenir shops, art center zone, and cottages zones. Based on the scenarios, the locations of proposed cottages zone is the tropical forest that is the home of the tropical forest biodiversity [15];[16]. However, no assessments have been conducted related to the forest, as well as aquatic ecosystem. This means that development plan lacks of ecological information.

\section{Coral Reef Structure}

The study of coral reefs structure of Balekambang coastal has been done in 2005. It was divided into three sections based on the land uses characters by tourist, east section, centre section and west section, respectively. The east section is the former destination, and still used intensively by tourist. The centre section recently uses intensively by tourist and become the target of tourism infrastructure development. The west section receive little number of tourist compared the centre and east sections. The overall study site and transect was mapped at Figure 1. 


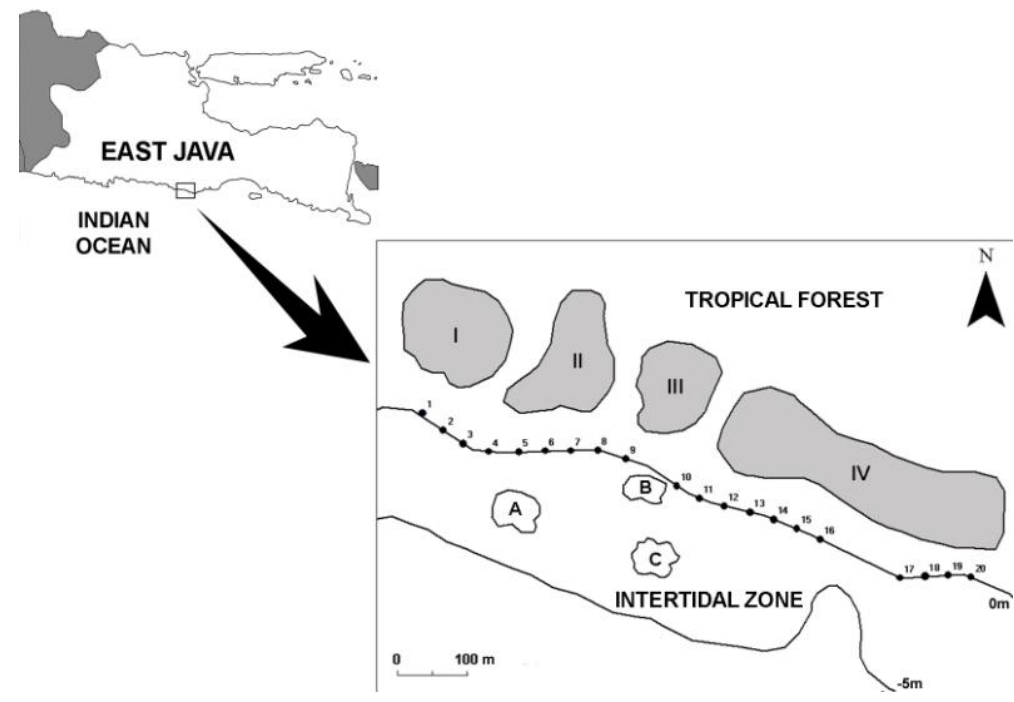

Figure 1. Map of East Java and location of study site. Dots number indicate locations of belt transect (stretch from shorelines to ocean at intertidal zone): $1-8$ laid out in west sector, 9-13 laid out in centre section and 14-20 laid out in east section. There are three islands, namely Wisanggeni (A), Hanuman (B) and Ismoyo (C). Area I is proposed become cottages area, II is planned become art centre exhibition, III is visitor center, and IV is proposed as parking area and restaurant zone.

Totally, twenty belt-transect were established at intertidal zone at the east, centre and the west sections of Balekambang. Every belt-transect had $200 \mathrm{~m}$ in length and consists of 15 plots of $1 \times 2 \mathrm{~m}$. Species relative density, relative dominance and relative frequency were measured in every plots. Morisita index was calculated to analyze the spatial distribution pattern of coral reefs community, and ShannonWeaver diversity index $\left(\mathrm{H}^{\prime}\right)$ was used to estimate biodiversity of community. Furthermore, importance value (IV) index was calculated to determine the relative importance of each species in the communities [18].

\section{Tourist Perspective for Balekambang Development \\ In order to understand the tourist} perspectives to Balekambang, an 8-item questionnaire regarding tourist perceptions and general ecological knowledge concerning Balekambang was formulated and distributed to 234 tourists during vacation days. It was followed by interviews approximately 15 to 20 minutes to explore respondents attitudes, particularly the uses of forest as a tourist object at Balekambang. Since respondents were diverse in educational background, tribes and language, and origins, the interviews were conducted using local language (Bahasa Jawa) and national language (Bahasa
Indonesia). All respondents were informed that their responses would be confidential [19].

\section{RESULTS AND DISCUSSIONS \\ Coral Reef Structure}

This study recorded 39 species of Coelenterata appear in Balekambang. Family of Acroporidae and Faviidae has the highest number of species (Table 1). Based on the Morisita index, every section of the study site was divided into several zones that reflected spatial distribution pattern of coral reefs community (Table 2). The table shows that the first zone of every section has the lowest diversity index compared to the next zones. Furthermore, it was followed by degree of coral disturbance among the first zone or zone located in range $0-100 \mathrm{~m}$ from the coastline that is heavily disturbed. It seems human activities during low tide affect coral destruction (Table 3).

\section{Tourist perspectives}

Of the 234 respondents, 144 were male $(61,5 \%)$ and 90 were female (38,5\%). Among 234 respondents, $22 \%$ has an age of $<20$ years old, $60 \%$ was $20-40$ years old, and $18 \%$ was $>40$ years old. The distribution of respondents origin were 51\% from towns surrounding Balekambang, 34\% from Malang City, $15 \%$ from other big city such as Surabaya. Result of the interviews was shown in Table 4. 
Table 1. List of species ware found at Balekambang during this study.

\begin{tabular}{|c|c|c|c|}
\hline No & Family & Genera & Species \\
\hline 1 & \multirow{8}{*}{ Acroporidae } & Acropora & Acropora sp. \\
\hline 2 & & Astreopora & Astreopora moretenensis \\
\hline 3 & & \multirow{6}{*}{ Montipora } & Montipora aequituberculata \\
\hline 4 & & & Montipora digitata \\
\hline 5 & & & Montipora efflurescens \\
\hline 6 & & & Montipora monasteriata \\
\hline 7 & & & Montipora tuberculata \\
\hline 8 & & & Montipora verrucosa \\
\hline 9 & Agariciidae & Leptoseris & Leptoseris sp. \\
\hline 10 & \multirow{4}{*}{ Dendrophyllidae } & Dendrophyllia & Dendrophyllia sp. \\
\hline 11 & & Tubastraea & Tubastraea sp. \\
\hline 12 & & \multirow[t]{2}{*}{ Turbinaria } & Turbinaria mesentarina \\
\hline 13 & & & Turbinaria peltata \\
\hline 14 & \multirow{8}{*}{ Faviidae } & \multirow{2}{*}{ Favia } & Favia lizardensis \\
\hline 15 & & & Favia speciosa \\
\hline 16 & & Favites & Favites complanata \\
\hline 17 & & \multirow{4}{*}{ Goniastrea } & Goniastrea australensis \\
\hline 18 & & & Goniastrea favulus \\
\hline 19 & & & Goniastrea pectinata \\
\hline 20 & & & Goniastrea retiformis \\
\hline 21 & & Plattigyra & Plattigyra lamellina \\
\hline 22 & \multirow{2}{*}{ Merulinidae } & Hydnophora & Hydnophora pilosa \\
\hline 23 & & Merulina & Merulina ampliata \\
\hline 24 & Milleporidae & Millepora & Millepora sp. \\
\hline 25 & \multirow{3}{*}{ Mussidae } & \multirow{3}{*}{ Lobophyllia } & Lobophyllia corymbosa \\
\hline 26 & & & Lobophyllia hataii \\
\hline 27 & & & Lobophyllia hemprichii \\
\hline 28 & Oculinidae & Galaxea & Galaxea sp. \\
\hline 29 & \multirow{4}{*}{ Pocilloporidae } & \multirow{4}{*}{ Pocillopora } & Pocillopora damicornis \\
\hline 30 & & & Pocillopora euydoxi \\
\hline 31 & & & Pocillopora meandrina \\
\hline 32 & & & Pocillopora verrucosa \\
\hline 33 & \multirow{5}{*}{ Poritidae } & Alveopora & Alveopora japonica \\
\hline 34 & & \multirow{3}{*}{ Goniopora } & Goniopora fruticosa \\
\hline 35 & & & Goniopora tenuidens. \\
\hline 36 & & & Goniopora sp \\
\hline 37 & & Porites & Porites sp. \\
\hline 38 & \multirow[t]{2}{*}{ Siderastreidae } & \multirow{2}{*}{ Psammacora } & Psammacora digitata \\
\hline 39 & & & Psammacora superficialis \\
\hline
\end{tabular}

Table 2. Coral reef structure of Balekambang. $H^{\prime}$ is Shannon-Weaver diversity index, and IV is important value index.

\begin{tabular}{|c|c|c|c|c|}
\hline Sections & Zones & $\mathbf{H}^{\prime}$ & Distance from coastline & Dominant or co dominant species \\
\hline \multirow{2}{*}{ East } & E.1 & 2.07 & $0-150 \mathrm{~m}$ & $\begin{array}{l}\text { Goniastrea australensis (IV = 16.41) and } \\
\text { Plattygyra lamellina }(\mathrm{IV}=14.81)\end{array}$ \\
\hline & E.2 & 2.72 & $151-200 \mathrm{~m}$ & Acropora sp (IV = 33.09) \\
\hline \multirow{5}{*}{ Center } & C.1 & 1.32 & $0-110 \mathrm{~m}$ & Goniastrea retiformis (IV = 34.22) \\
\hline & C.2 & 3.89. & $111-130 \mathrm{~m}$ & Acrophora sp. (IV = 30.66) \\
\hline & C.3 & 3.27 . & $131-160 \mathrm{~m}$ & $\begin{array}{l}\text { Montipora efflurescens (IV = 18.81) and } \\
\text { Plattigyra lamellina }(\mathrm{IV}=22.80)\end{array}$ \\
\hline & C. 4 & 4.20 & $161-180 \mathrm{~m}$ & $\begin{array}{l}\text { Astreophora moretenensis (IV = 32.50) and } \\
\text { Goniastrea australensis (IV = 21.26) }\end{array}$ \\
\hline & C.5 & 3.53 & $181-200 \mathrm{~m}$ & $\begin{array}{l}\text { Astreophora moretenensis (IV = 23.42) and } \\
\text { Plattigyra lamellina (IV = 23.42) }\end{array}$ \\
\hline \multirow{4}{*}{ West } & W.1 & 3,13 & $0-90 \mathrm{~m}$ & Acrophora sp (IV = 57.38) \\
\hline & W.2 & 3,96 . & $91-150 \mathrm{~m}$ & Acrophora sp (IV =31.80) \\
\hline & W.3 & 3,96 & $151-180 \mathrm{~m}$ & $\begin{array}{l}\text { Montipora efflurescens (IV = 18.17) and } \\
\text { Plattigyra lamellina (IV = 22.64) }\end{array}$ \\
\hline & W.4 & 3,53 . & $181-200 \mathrm{~m}$ & $\begin{array}{l}\text { Plattigyra lamellina (IV = 23.78) and } \\
\text { Pocillophora verrucosa (IV = 21.63), }\end{array}$ \\
\hline
\end{tabular}


Most (77\%) of the respondents argue that Balekambang was beautiful, expressed their interest to coastal destination. Interestingly, $11 \%$ of the respondents stated that the area was not beautiful because the quality of Balekambang decrease compared $10-5$ years ago. About $65 \%$ respondents stated their dissatisfaction with the current environmental conditions, mainly due to waste abundance in everywhere and the beach was crowded by visitors. The issues of visitors number seems to be managed since $82 \%$ respondents state that Balekambang was very crowded by visitors. Following interviews, several respondents stated that the destination enlargement was needed to accommodate tourist arrival. Respondents knew (74\%) that coral ecosystem being affected by tourist activities, especially during low tide when tourist enters to the coral reefs ecosystem. Respondents knew the role of the forest in their live (74\%), and they knew that forest can be used as tourist destination. Following interview, most tourists stated that forest in Balekambang could be developed to become tourist destination such Cangar Grand Forest in Malang or Purwodadi Botanical Garden in Pasuruan. Most of the respondents (89\%) agreed that the forest would be developed as a destination. Following the interviews, respondents stated that the role of forest as destination may lead to educational purposes and also conservation program opportunities.

Table 3. Percentage of coral reef disturbance and tourist activities during low tide as observed during this study

\begin{tabular}{|c|c|c|c|c|}
\hline Sections & Zones & $\begin{array}{l}\text { Distance from } \\
\text { coastline }\end{array}$ & $\begin{array}{c}\text { Coral reef } \\
\text { disturbance }\end{array}$ & $\begin{array}{c}\text { Tourist activities during } \\
\text { low tide }\end{array}$ \\
\hline \multirow{2}{*}{ East } & E.1 & $0-150 \mathrm{~m}$ & $50 \%$ & yes \\
\hline & E.2 & $151-200 \mathrm{~m}$ & $3 \%$ & no \\
\hline \multirow{5}{*}{ Center } & C.1 & $0-110 \mathrm{~m}$ & $59 \%$ & yes \\
\hline & C. 2 & $111-130 \mathrm{~m}$ & $16 \%$ & yes \\
\hline & C.3 & $131-160 \mathrm{~m}$ & $0 \%$ & no \\
\hline & C. 4 & $161-180 \mathrm{~m}$ & $0 \%$ & no \\
\hline & C.5 & $181-200 \mathrm{~m}$ & $0 \%$ & no \\
\hline \multirow{4}{*}{ West } & W.1 & $0-90 \mathrm{~m}$ & $11 \%$ & yes \\
\hline & W.2 & $91-150 \mathrm{~m}$ & $3 \%$ & yes \\
\hline & W.3 & $151-180 \mathrm{~m}$ & $0 \%$ & no \\
\hline & W.4 & $181-200 \mathrm{~m}$ & $0 \%$ & no \\
\hline
\end{tabular}

Table 4. Tourist responses to questions concerning Balekambang $(n=234)$

\begin{tabular}{|c|c|c|}
\hline Questions & Response & Percent \\
\hline \multirow{3}{*}{$\begin{array}{l}\text { What is your perception about Balekambang landscape as a tourist } \\
\text { destination? }\end{array}$} & Beautiful & 77 \\
\hline & Uncertain & 12 \\
\hline & Not beautiful & 11 \\
\hline \multirow{3}{*}{ Are you satisfy with the current environment of Balekambang? } & Yes & 28 \\
\hline & Uncertain & 7 \\
\hline & No & 65 \\
\hline \multirow{3}{*}{ Is it important to add and diversify tourist object? } & Yes & 93 \\
\hline & Uncertain & 7 \\
\hline & No & 0 \\
\hline \multirow{3}{*}{ What do you think about number of tourist visiting Balekambang? } & Much and crowded & 82 \\
\hline & Uncertain & 0 \\
\hline & Less and not crowded & 18 \\
\hline \multirow{3}{*}{$\begin{array}{l}\text { Are the coral reefs affected by tourism activities such as fishing, swimming, } \\
\text { and collecting marine creatures? }\end{array}$} & Yes & 74 \\
\hline & Uncertain & 3 \\
\hline & No & 23 \\
\hline \multirow{3}{*}{ Did you know the role of forest in your life? } & Yes & 74 \\
\hline & Uncertain & 10 \\
\hline & No & 16 \\
\hline \multirow{3}{*}{ Is the forest potential to develop as tourism object? } & Yes & 80 \\
\hline & Uncertain & 18 \\
\hline & No & 2 \\
\hline \multirow{3}{*}{$\begin{array}{l}\text { Are you in favor that the forest should be managed as atourist } \\
\text { destination? }\end{array}$} & Agree & 89 \\
\hline & Uncertain & 8 \\
\hline & Disagree & 3 \\
\hline
\end{tabular}




\section{Discussion}

Formerly, the beauty of coral reefs spread out from east to the west of Balekambang. Immediately after the area was opened as tourism destination, the east section intensively used as tourist destination. The children playing ground, camping ground, parking area was established, and restaurants as well as souvenir shops grows rapidly. Then, the centre section received more visitors due to tourist arrival growth simultaneously. However, the tourism growth seems uncontrolled and less of destination management system lead corals disturbance in east and centre section, which indicated by lowest diversity index among such zone and the degree of destruction. Hence, impact of tourism activities to environments is significant as shown by some scholars [4]; [20].

Recently, several coral reefs species are distributed at intertidal zone of Balekambang under tourism pressure. While there are no data related previous species diversity and richness, the occurrence of coral reefs species was indicators that Balekambang is one of the best coral reefs habitat in southern coast of Java Island. The existence of Acroporids corals (Acroporidae) has important role in disturbed coral reefs for its resilience. Acroporids plays an important role within reefs communities by providing the geological, physical and biological foundations for the development of numerous shallow reef communities [21]. However, since Acroporids are very popular and become the targets of reef collectors and tourist [8]; [4], the attention to Acropids was needed, as well as other species of corals in Balekambang.

Meanwhile, the coral reefs structure in the west seems more diverse, the threats to destruction come from cottage development planning. The impact of cottage development was identified by several authors lead to siltation and pollution from the land to the sea (Burak, 2004). Ironically, the development it self will converse tropical forest become cottage development. Hence, the planning of cottage development seems to be reviewed to meet sustainability uses, both for terrestrial and aquatic uses. Social perspectives, especially from tourists, supported the future challenge of this argument. Mostly, visitor seems not to agree with this plan, and it was reflected by their opinion during interview. The cottages are very exclusive, and not all visitors have an access to such cottage. They show several failure of cottage development, and their opinion was supported by the data of tourist arrivals and hostel occupation during 1997 to 2004 [21].

The forest park seems to be the solution to meet sustainability. The benefits from forest park will not only to diversify the tourist object, but comes from several arguments. Forest park will become place to conserve lowland tropical forest, protecting aquatic ecosystem from physical disturbance coming from terrestrial ecosystem, a place to learn about vegetation as well as botanical garden, reducing crowded tourist along sandy beach and importantly lead visitors not to enter coral reefs ecosystem during low tide. It seems will lead integrated coastal zone management models, as applied in several countries [9].

\section{CONCLUSION}

The ecological and social evaluation of Balekambang as coastal tourism destination shows that integrated planning is urgently needed to achieve sustainability. The proposed documents for development needs to be reviewed due to the lacks of consideration on coral reefs conservation, which now threatened by tourism activities. A development scenario that potentially leads to ecosystem degradation, both in terrestrial and aquatic, should be reviewed. Hence, we suggest that development planning for Balekambang should be drawn integrally

\section{REFERENCE}

[1]. Heywood, V. H and Watson, R.T.1995. Global Biodiversity Assessment. UNEPCambridge University Press.

[2]. Allen, G. and R. Steeve. 1998. Indo-Pacific Coral Reefs Field Guide. Sea Challengers.

[3]. Lesser, M.P. 2004. Experimental biology of coral reef ecosystems. Journal of Experimental Marine Biology and Ecology 300: 217-252.

[4]. Tomascik, T., A.J. Mah., A. Nontji, M.K. Moosa. 1997. The Ecology of the Indonesia seas part two. The ecology of Indonesia series. Volume VIII.Periplus edition.

[5]. Moberg, F and C. Folke. 1999. Ecological goods and services of coral reef ecosystems. Ecological economics 29: 215-233.

[6]. Jaap, W.C. 2000. Coral reef restoration. Ecological engineering 15: 345-364.

[7]. Hall, C.M. 2001. Trends in ocean and coastal tourism: the end of the last frontier? Ocean and Coastal Management 44: 601-618. 
[8]. Whitten, R.E. Soeriaatmadja, S.A. Afiff. 1996. The Ecology of Java and Bali. The ecology of Indonesia series. Volume III. Periplus edition.

[9]. Gibson, J., M. McField and S. Wells. 1998. Coral reef management in Belize: an approach through Integrated Coastal Zone Management. Ocean and Coastal Management 39: 229-244.

[10]. Jennings, S. 2004. Coastal tourism and shoreline management. Annals of Tourism Research. 31 (4):889-922.

[11]. Gunn, C.A and T. Var. 2002. Tourism Planning: Basics, Concepts and Cases. Fourth edition. Routledge Taylor and Francis Group.

[12]. Jennifer L.W, B. Mitchell and S. Wismer. 2000. Impacts during project anticipation in Molas, Indonesia: Implications for social impact assessment. Environmental Impact Assessment Review 20 (5): 513-535.

[13]. D'haeze, D., J. Deckers, D. Raes, T. A. Phong and H. V. Loi 2005. Environmental and socioeconomic impacts of institutional reforms on the agricultural sector of Vietnam: Land suitability assessment for Robusta coffee in the Dak Gan region. Agriculture, Ecosystems \& Environment, 105 (1-2):59-76.

[14]. Liyama, N. M. Kamada and N. Nakagoshi. 2005. Ecological and social evaluation of landscape in rural area with terraced paddies in southern Japan. Landscape and Urban Planning 73: 60-71.

[15]. Government of Malang Regency. 1994. The Mater Plan for Tourism Development of Malang Regency. Malang Regency Official Document, East Java, Indonesia.

[16]. Government of Malang Regency. 1995. Site Plan for Tourism Destination Development: Balekambang and Ngliyep. Malang Regency Official Document, East Java, Indonesia.

[17]. Jasa Yasa. 2004. Tourism Statistics of Malang Regency. Government of Malang Regency, East Java, Indonesia.

[18]. Krebs, C.J. 1998. Ecological Methodology. Second ecition. Benjamin Cummings.

[19]. Bernards, R. 2001. Research Methods in Anthropology: Qualitative and Quantitative Approaches. Third edition. Altamira Press.

[20]. Burak, S., E. Dogan and C. Gazioglu. 2004. Impact of urbanization and tourism on coastal environment. Ocean and Coastal Management. 47: 515-527.

[21]. Bruckner, A.W. 2002. Proceeding of the Caribbean Acropora Workshop: Potential application of the U.S. Endangered Species Act as a Conservation Strategy. NOAA. Technical Memorandum NMFS-OPR-24. Silver Spring, MD.

[22]. DCT-Gol. 2005. Number of visitor arrivals to Indonesia and revenue from international tourist, 1969-2003. Department of Culture and Tourism Republic of Indonesia. 